INOBIS: Jurnal Inovasi Bisnis dan Manajemen Indonesia

Volume 1, Nomor 1, Desember 2017

Moh. Agus Salim Monoarfa

\title{
Strategi Penetapan Harga Dalam Rantai Pasok
}

\author{
Moh. Agus Salim Monoarfa \\ Mahasiswa Program Doktor Ilmu Manajemen, Universitas Brawijaya \\ agusmonoarfa@ung.ac.id
}

\begin{abstract}
Abstrak
Keputusan penentuan harga juga sering dilakukan dengan mengasumsikan apakah kondisi pasar/keadaan itu pasti (certainty) atau sebaliknya berada dalam sebuah ketidakpastian (uncertainty). Berbagai macam metode dan fungsi yang digunakan untuk menentukan harga untuk dua kondisi atau keadaan tersebut. Adapun metode-metode penentuanharga lebih banyak hanya berdasarkan informasi saja. Salah satu tanggung jawab seorang manajer pemasaran adalah menetukan harga produk atau lini produk dalam lingkungan strategi harga yang dinamis. Bentuk fleksibilitas semacam itu dimaksudkan agar strategi yang dianut mampu dipergunakan untuk mengantisipasi desakan faktor lingkungan eksternal, misalnya permintaan konsumen, persaingan, kondisi perekonomian secara makro, serta berbagai bentuk hukum dan peraturan perundangan yang berlaku. Pada umumnya penentuan harga sangat bergantung pada keadaan suatu pasar. Strategi Harga dengan sendirinya akan mengikuti struktur pasar.
\end{abstract}

Keywords: Strategi Harga, Rantai Pasok

\section{Pendahuluan}

Perubahan atau penyesuaian harga dipengaruhi oleh beberapa factor seperti : (1) meningkatnya sensitivitas konsumen terhadap harga, terutama pada masa inflasi harga menjadi patokan untuk keputusan pembelian; (2) meningkatnya penggunaan merek lokal dan merek generik sehingga menekan pengunaan merek nasional secara bebas; dan (3) meningkatnya volume peluncuran produk baru, yang berarti membutuhkan reevaluasi yang terus menerus terhadap harga produk. Keputusan penentuan harga juga sering dilakukan dengan mengasumsikan apakah kondisi pasar/keadaan itu pasti (certainty) atau sebaliknya berada dalam sebuah ketidakpastian (uncertainty).

Berbagai macam metode dan fungsi yang digunakan untuk menentukan harga untuk dua kondisi atau keadaan tersebut. Adapun metode-metode penentuanharga lebih banyak hanya berdasarkan informasi saja. Untuk dapat yakin terhadap harga yang telah diperoleh tersebut, maka kita harus yakin pula bahwa hasil penaksiran permintaan dan biayanya betulbetul menujukkan keadaan yang actual dan bahwa asumsi ceteris paribus yang mendasarinya diharapkan benar-benar teradi. Misalnya, jika perhitungan menunjukkan bahwa harga produk kita jauh lebih rendah dari harga saingan terdekat, maka kita bisa memperkirakan bahwa perusahaan saingan tersebut akan bereaksi dan karenanya asumsi seteris paribus tersebut tidak berlaku. Oleh karena data permintaan dan biaya hanya merupakan hasil penaksiran, maka hasil yang actual bisa sangat berbeda dengan hasil yang diharapkan. Inilah sifat dari proses pengembilan keputusan dalam keadaan yang tidak pasti. Namun demikian, kita harus dapat membuat keputusan berdasarkan informasi yang terbaik yang kita milikim dan jika ada informasi baru yang datang belakangan, maka informasi baru tersebut akan merupakan dasar bagi keputusan berikutnya. 
INOBIS: Jurnal Inovasi Bisnis dan Manajemen Indonesia

Volume 1, Nomor 1, Desember 2017

Moh. Agus Salim Monoarfa

\section{Pembahasan}

\subsection{Dynamic ordering and pricing strategies in a two-tier multi-generation durable goods supply chain}

Junxiu Jia, Jiang Zhang (2013), Penelitian ini dilakukan dengan mempertimbangkan masalah harga dan keputusan pemesanan yang dinamis untuk produk yang tahan lama dengan beberapa generasi dalam rantai pasokan dengan salah satu produsen dan satu pengecer, dimana produsen memperkenalkan generasi baru dari produk yang tahan lama sebelum generasi terakhir keluar dipasar. Dalam hal ini, tuntutan untuk produk yang berkualitas dan harga sangat sensitive. Untuk setiap generasi, produsen menentukan harga grosir dan tingkat kualitas, sementara pengecer memutuskan kuantitas dan harga ritel disetiap periode pembelian. Hal ini berarti bahwa keduanya (produsen dan pengecer) ingin memaksimalkan keuntungan yang diharapkan.

Penelitian ini menganalisis proses peluncuran produk dari produk multi generasi yang tahan lama dalam sebuat rantai pasokan. Sehingga perlu menetapkan model strategis dari keputusan harga dan kualitas untuk produsen. Pengecer akan mempertimbangkan utilitas konsumen dengan sensitifitas harga dan kualitas dalam setiap periode pembelian. Hubungan antara berbagai variable dalam rantai pasokan juga perlu dibahas. Penelitian ini menunjukan bahwa strategi harga yang optimal dari pengecer bergantung pada sensitifitas harga dan kualitas ptoduk yang diberikan kepada konsumen. Sehingga produsen akan dapat menentukan strategi harga dan kualitas yang optimal berdasarkan tingkat sensitifitas harga dan kualitas yang diperoleh pengecer dari konsumen.

Dalam penelitian ini diberikan contoh numeric yang menunjukan (1) dengan tingkat kualitas produk yang diberikan, harga pengecer menurun dengan meningkatnya sensitifitas harga konsumen. (2) tingkat kualitas produk meningkat dengan meningkatnya sensitfitas kualitas ketika harga eceran tetap sama dalam periode pembelian yang berbeda.

Rekomendasi dalam penelitian ini adalah : Pertama, dimasa depan perlu mengeksplorasi masalah dengan beberapa jumlah generasi produk dalam periode pembelian, karena dalam penelitian ini hanya digunakan dua generasi dalam setiap priode pembelian. Kedua, perlu juga untuk membandingkan strategi rantai pasokan yang terpusat, sehingga akan meningkatkan kinerja dari rantai pasokan

\subsection{The Research on Pricing Strategy for Perishable High-tech Products Based on Circular Economy.}

Yang Zhilei, Wang Wei (2011), menunjukkan bahwa perilaku pembelian konsumen tergantung pada apa dan berapa banyak yang bisa ia dapatkan dari produk, dan harga merupakan faktor penentu untuk utilitas konsumen. Produsen dapat mencapai manfaat maksimalisasi melalui membuat strategi harga yang wajar. Artikel ini menetapkan manfaat fungsi dari produsen di "Trade All for New", dan melalui analisis contoh, studi pengaruh untuk 'perilaku pembelian dan produsen' oleh konsumen manfaat dengan 'perdagangan barang tua untuk harga baru dan harga pemesanan produk konsumen.

Dalam peelitian ini diketahui bahwa Harga pemesanan konsumen akan mempengaruhi langsung ke perilaku pembelian konsumen, dan kemudian mempengaruhi rasio konsumen yang mengambil bagian dalam kegiatan " trade old for new ", dan akhirnya mempengaruhi keuntungan penjualan dari produsen. Produsen dapat mencapai tujuan manfaat maksimisasi melalui strategi harga yang wajar. Penelitian artikel ini strategi harga "trade old for new" 
INOBIS: Jurnal Inovasi Bisnis dan Manajemen Indonesia

Volume 1, Nomor 1, Desember 2017

Moh. Agus Salim Monoarfa

hanya ketika produk lama tidak dijual lagi. Jadi itu adalah untuk dibahas lebih lanjut untuk produk lama akan saled lagi oleh manufaktur lebih lanjut atau membarui.

\subsection{Manufacturer's pricing strategy for supply chain with warranty period-dependent demand}

Xu Chen, LingLi, MingZhou (2012), menyajikan tinjauan isu yang terkait dengan strategi harga dari produsen dalam rantai pasokan dua eselon yang terdiri dari satu produsen dan dua pengecer bersaing, dengan garansi periode tergantung permintaan. produsen, sebagai pemimpin Stackelberg, menentukan harga grosir untuk dua pengecer bersaing yang menghadapi garansi periode tergantung permintaan dan memiliki biaya penjualan yang berbeda. produsen menganggap tiga pilihan harga: (1) menetapkan harga yang sama untuk kedua pengecer, sementara mengabaikan perbedaan mereka berkaitan dengan biaya penjualan; (2) menetapkan harga yang berbeda untuk masing-masing pengecer atas dasar biaya penjualan mereka; dan (3) menetapkan harga yang sama untuk kedua pengecer sesuai dengan biaya rata-rata penjualan industri.

Pada artikel ini, periode pengecer 'optimal garansi dan laba optimal, harga grosir optimal produsen, dan / keuntungan yang optimal nya terkait dengan strategi harga yang berbeda telah diturunkan dengan menggunakan teori permainan. Analisis kami menunjukkan bahwa hasil untuk pengecer adalah sama dengan Strategi 1 atau Strategi 3. Selain itu, kami membandingkan efek dari strategi harga yang berbeda dari produsen pada keputusan rantai pasokan dan keuntungan. Kami menyimpulkan dari hasil bahwa produsen harus baik mengadopsi Strategi 2 dengan informasi biaya penjualan simetris atau Strategi 3 jika biaya penjualan pengecer 'yang asimetris.

\subsection{Impact of cost uncertainty on pricing decisions under risk aversion}

Sechan Oh, James Rhodes, Ray Strong (2016), penelitian ini difokuskan pada biaya ketidakpastian dalam layanan. Dalam penelitian ini yagn pertama diidentifikasi adalah akar penyebab dari biaya ketidakpastian. Kebanyakan literature hanya melihat biaya ketidakpastian itu pada industry manufaktur, sementara untuk sector jasa cenderung diabaikan. Selanjutnya dalam penelitian ini akan diselidiki bagaimana biaya ketidakpastian dapat mempengaruhi keputusan penetapan harga penyedia jasa dengan menghindari resiko dalam memberikan pelayanan.

Penelitian menunjukkan bahwa biaya ketidakpastian selalu meningkatkan harga, di mana hal ini adalah dampak dari ketidakpastian permintaan. Penelitian ini menunjukkan bahwa di bawah penaksiran dan permintaan ketidakpastian aditif model menentu, ketidakpastian permintaan mengurangi harga yang optimal, dan di bawah model ketidakpastian permintaan perkalian, ketidakpastian permintaan tidak memiliki dampak langsung pada harga yang optimal.

\subsection{The impact of the internet on the pricing strategies of the European low cost airlines}

Selanjutnya penelitian yang dilakukan oleh L.Moreno-Izquierdo, A.Ramón-Rodríguez, J.Perles Ribes (2015). Penelitian ini bertujuan untuk menganalisis penentuan harga penerbangan dengan biaya rendah di Eropa dan efek bahwa internet memiliki strategi ini. Hasil yang diperoleh menunjukkan bahwa kedua pengguna dan perusahaan mendapatkan keuntungan dari penggunaan TIK dalam pembelian dan penjualan tiket maskapai 
INOBIS: Jurnal Inovasi Bisnis dan Manajemen Indonesia

Volume 1, Nomor 1, Desember 2017

\section{Moh. Agus Salim Monoarfa}

penerbangan: internet memungkinkan konsumen untuk meningkatkan daya tawar mereka membandingkan penerbangan yang berbeda dan memilih penerbangan yang paling kompetitif, sementara perusahaan dapat dengan mudah memeriksa perilaku pengguna untuk menyesuaikan strategi harga mereka menggunakan informasi internal.

Lebih dari 2500 penerbangan dari maskapai penerbangan biaya rendah terbesar di Eropa telah digunakan untuk melaksanakan penelitian. Hasil penelitian menunjukkan bahwa variabel yang paling signifikan atau strategi penetapan harga pemahaman yang jumlah saingan, perilaku variabel yang paling signifikan dari pemahaman strategi penetapan harga yang jumlah saingan, perilaku permintaan dan biaya yang terkait. Hasil penelitian menunjukkan bahwa konsumen harus membeli tiket sebelum 25 hari sebelum keberangkatan.

Singkatnya, hasil yang diperoleh dalam penelitian ini konsisten dengan yang ditemukan oleh penulis seperti malighetti, et. al (2009), bachis dan Piga (2011) atau salanti, et al. (2012). Penggabungan variabel baru dapat dianggap sebagai langkah lebih lanjut dalam penelitian dari biaya rendah segmen penerbangan yang harus terus menganalisis bagaimana produk pelengkap, pemerintah dan teknologi khususnya baru kondisi akses oleh permintaan dan strategi perusahaan penerbangan.

\subsection{Determinants of consumers' response to pay-what-you-want pricing strategy on the Internet}

Fei L.Weisstein, Monika Kukar-Kinney, Kent B.Monroe (2016). Dalam penelitian ini menggunakan pendekatan harga yang dalam produk yang dijual online. Penelitian ini mengeksplorasi efek dari pay what you want (bayar apa yang anda inginkan) di internet. Untuk menekankan hal ini maka sangat dibutuhkan teori-teori tentang komunikasi dan harga. Hasil penelitian menunjukan bahwa niat konsumen melakukan pembelian secara online dipengaruhi oelh pengetahuan produk yang dirasakan mereka, sementara kualitas yang dirasakan akan mempengaruhi harga. Rekomendasi dalam peneltiian ini adalah bahwa penelitian dimasa depan dapat menyelidiki komponen tambahan yang dapat meningkatkan persepsi konsumen untuk melakukan pembelian lewat internet.

\section{Simpulan dan Keterbatasan}

Pada umumnya penentuan keputusan harga sangat bergantung pada keadaan suatu pasar. Pricing decision dengan sendirinya akan mengikuti struktur pasar. Produsen atau perusahaan yang beroperasi dalam pasar persaingan sempurna sering disebut dengan "price takers". Sebaliknya untuk pasar monopolitik, oligopoly dan monopoli perusahaan atau produsen dapat menjadi "price makers".

Artikel ini hanya menyampaikan kembali penelitian-penelitian terdahulu yang berkaitan dengan pricing decision, sementara pricing strategy akan sangat ditentukan oleh keadaan dan bentuk suatu pasar.

\section{Referensi}

Fei L.Weisstein, Monika Kukar-Kinney, Kent B.Monroe. (2016). Determinants of Consumers' response to pay-what-you-want pricing strategy on the Internet. Journal of Business Research 69: 4313-4320 
INOBIS: Jurnal Inovasi Bisnis dan Manajemen Indonesia

Volume 1, Nomor 1, Desember 2017

Moh. Agus Salim Monoarfa

L.Moreno-Izquierdo, A.Ramón-Rodríguez, J. Perles Ribes. (2015). The impact of the internet on the pricing strategies of the European low cost airlines. European Journal of Operational Research $246: 651-660$

Junxiu Jia, Jiang Zhang. (2013). Dynamic ordering and pricing strategies in a two-tier multigeneration durable goods supply chain. Int. J. Production Economics 144:135-142

Sechan Oh, James Rhodes, Ray Strong (2016). Impact of cost uncertainty on pricing decisions under risk aversion. European Journal of Operational Research 253 : 144153

Xu Chen, Ling Li, Ming Zhou. (2012). Manufacturer's pricing strategy for supply chain with warranty period-dependent demand. Omega $40: 807-816$

Yang Zhilei, Wang Wei. (2010). The Research on Pricing Strategy for Perishable High-tech Products Based on Circular Economy. Energy Procedia 5 : 1842-1846. 